\title{
Distribution, prevalence, and genetic analysis of Panulirus argus virus 1 (PaV1) from the Caribbean Sea
}

\author{
Jessica Moss ${ }^{1, *}$, Donald Behringer ${ }^{2,3}$, Jeffrey D. Shields ${ }^{1}$, Antonio Baeza ${ }^{4,5}$, Alfonso \\ Aguilar-Perera ${ }^{6}$, Phillippe G. Bush ${ }^{7}$, Clement Dromer $^{8}$, Alejandro Herrera-Moreno ${ }^{9}$, \\ Lester Gittens $^{4,10}$, Thomas R. Matthews ${ }^{11}$, Michael R. McCord ${ }^{12}$, Michelle T. Schärer ${ }^{13}$, \\ Lionel Reynal ${ }^{8}$, Nathanial Truelove ${ }^{14}$, Mark J. Butler ${ }^{4}$ \\ ${ }^{1}$ Dept. of Environmental and Aquatic Animal Health, Virginia Institute of Marine Science, \\ College of William and Mary, Greate Road, Gloucester Point, Virginia 23062, USA \\ ${ }^{2}$ School of Forest Resources and Conservation, Fisheries and Aquatic Sciences, University of Florida, Gainesville, Florida 32653, USA \\ ${ }^{3}$ Emerging Pathogens Institute, University of Florida, Gainesville, Florida 32610, USA \\ ${ }^{4}$ Dept. of Biological Sciences, Old Dominion University, Norfolk, Virginia 23529, USA \\ ${ }^{5}$ Smithsonian Marine Station at Fort Pierce, Fort Pierce, Florida 34949, USA \\ ${ }^{6}$ Dep. de Biología Marina, Facultad de Medicina Veterinaria y Zootecnia, Universidad Autónoma de Yucatán, Mérida, Mexico \\ ${ }^{7}$ Dept. of Environment, Cayman Islands Government, CI Environmental Center, Grand Cayman, Cayman Islands \\ ${ }^{8}$ Institut Français de Recherche pour l'Exploitation de la Mer (Ifremer), Pointe Fort 97231, Martinique \\ ${ }^{9}$ Programa EcoMar Inc., Santo Domingo 10700-11999, Dominican Republic \\ ${ }^{10}$ Dept. of Marine Resources, Ministry of Agriculture and Marine Fisheries, Government of the Bahamas, Nassau 3028, Bahamas \\ ${ }^{11}$ Florida Fish and Wildlife Conservation Commission, Fish and Wildlife Research Institute, Marathon, Florida 33050, USA \\ ${ }^{12}$ Naval Facilities Engineering Command (NAVFAC) Environmental Division, US Naval Base, Guantanamo Bay, Cuba \\ ${ }^{13}$ Dept. of Marine Science, University of Puerto Rico, Mayagüez, Puerto Rico 00681 \\ ${ }^{14}$ Faculty of Life Sciences, University of Manchester, Manchester, M13 9PL, UK
}

\begin{abstract}
The pathogenic virus Panulirus argus virus 1 (PaV1) was first discovered in Caribbean spiny lobsters Panulirus argus from the Florida Keys (USA) in 1999 and has since been reported in Belize, Mexico, and Cuba; its distribution in the wider Caribbean is unknown. We collected tissue samples from adult spiny lobsters from 30 locations in 14 countries bordering the Caribbean Sea and used molecular diagnostics to assay for the presence of PaV1. PaV1 occurred primarily in the northern areas of the Caribbean, where its prevalence was highest. The virus was not found in lobsters from the southeastern Caribbean, and its prevalence was lowest in the southwestern Caribbean. DNA sequence analysis was performed on a fragment of the viral DNA to examine the genetic diversity of PaV1 on a Caribbean-wide scale. Sequence variation in the viral DNA fragment was high, with 61 unique alleles identified from 9 areas. The sharing of viral alleles in lobsters from distant locations supports the hypothesis of a strong genetic connectivity among lobsters within the Caribbean, and further supports the hypothesis that postlarvae infected with PaV1 may serve to disperse the virus over long distances.
\end{abstract}

KEY WORDS: Spiny lobster $\cdot$ Disease $\cdot$ Epidemiology $\cdot$ Connectivity

\section{INTRODUCTION}

The Caribbean spiny lobster Panulirus argus is abundant throughout the Caribbean Sea and Gulf of Mexico, where it is widely fished, both commercially and recreationally. However, $P$. argus is also found in the northwestern Atlantic (e.g. North Carolina, USA, and Bermuda), and a few vagrants have been identified from as far away as western Europe and Africa (Freitas \& Castro 2005). Over the period 1987 to 2001, 
the commercial harvest of $P$. argus in Florida, USA, totaled 42 million $\mathrm{kg}$, valued at US\$365.3 million (Florida Wildlife and Conservation Commission 2012). In 2010, more than 35000 metric tons (t) of $P$. argus were landed worldwide (FAO Fisheries and Aquaculture Information and Statistics Service). Countries with the highest landings include Brazil, the Bahamas, Cuba, Nicaragua, Honduras, the Dominican Republic, and the USA (Vondruska 2010).

In 1999, a pathogenic virus, Panulirus argus virus 1 (PaV1), was discovered infecting spiny lobsters from the Florida Keys (Shields \& Behringer 2004). Prevalence of PaV1 is highest in early benthic juveniles (EBJs) and lower among larger juveniles and adults (Shields \& Behringer 2004, Butler et al. 2008, LozanoÁlvarez et al. 2008). Lobsters with clinical disease have chalky-white hemolymph and often have a discolored carapace with a pink hue. Heavily infected lobsters are typically lethargic, cease grooming and foraging, and have lower hemolymph serum protein values compared to uninfected lobsters (Behringer et al. 2008). Histologically, signs of PaV1 infection include a depletion of the reserve inclusion cells, hemocyte infiltration into the intertubular spaces of the hepatopancreas, focal necrosis of the hepatopancreas, and the presence of infected hemocytes in the heart, gills, and connective tissues (Li et al. 2008).

Since its initial discovery in Florida, infections have been confirmed in Belize (Huchin-Mian et al. 2009), Mexico (Huchin-Mian et al. 2008), Cuba (Cruz Quintana et al. 2011), and the US Virgin Islands (Butler et al. 2008). Prevalence of PaV1 in juvenile lobsters in Florida is patchy, but has historically ranged from 5 to $8 \%$, with some locations exceeding $60 \%$ (Behringer et al. 2011). While typically asymptomatic, adult lobsters can be infected by PaV1, as determined through PCR screening of adults in Florida (prevalence: $11 \%$; Behringer et al. 2012), Belize (prevalence in frozen tails: 50\%; Huchin-Mian et al. 2009), and Cuba (prevalence: 0.95\%; Cruz Quintana et al. 2011).

Inspection of lobster hemolymph viewed through the juncture of the abdomen and ventral carapace is still commonly used to diagnose PaV1 infections, but that method only reveals the most severely diseased individuals whose hemolymph is white. Animals with light and moderate infections cannot be diagnosed visually, and adult lobsters are typically asymptomatic. An assay using PCR is an accurate and sensitive diagnostic method for PaV1 that amplifies an approximately 500 bp viral DNA fragment (GenBank accession no. EF206313) (Montgomery-Fullerton et al. 2007). Molecular detection of viral DNA using PCR has been used to diagnose
PaV1 in Panulirus argus from Florida (Behringer et al. 2011, 2012, Moss et al. 2012), Mexico (HuchinMian et al. 2008), Belize (Huchin-Mian et al. 2009), and Cuba (Cruz Quintana et al. 2011). Sequencing of the $500 \mathrm{bp}$ fragment of viral DNA has revealed high genetic variation in PaV1 from postlarval and juvenile lobsters collected throughout the Florida Keys (Moss et al. 2012).

Due to the relatively recent discovery of PaV1 in adult lobsters in Belize, Cuba, and Florida (HuchinMian et al. 2009, Cruz Quintana et al. 2011, Behringer et al. 2012), in addition to our recent discovery of genetic variability in the virus (Moss et al. 2012), we undertook an extensive survey to assess the distribution, prevalence, and genetic variation of PaV1 in adult spiny lobsters from around the Caribbean Sea. Our objectives were to assess the prevalence of the virus in adults from countries around the Caribbean, to examine the genetic diversity of the virus from different regions, and to examine patterns in the diversity of the virus in relation to the spatial connectivity of regions within the Caribbean.

\section{MATERIALS AND METHODS}

\section{Sample collection}

Hemolymph samples from sublegal- and legalsized (carapace length $\geq 75 \mathrm{~mm}$ ) Panulirus argus were obtained during 2008 and 2009 onboard commercial fishing vessels in Florida (see Behringer et al. 2011 for full details). Approximately $200 \mu \mathrm{l}$ of hemolymph was withdrawn using a sterile syringe inserted at the base of the 5th walking leg and dispensed into $600 \mu \mathrm{l}$ of sterile sodium-citrate lobster anticoagulant (0.45 M NaCl, $0.1 \mathrm{M}$ glucose, $30 \mathrm{mM}$ sodium citrate, $26 \mathrm{mM}$ citric acid, 10 mM EDTA; pH 4.6 to 5.4; Söderhäll \& Smith 1983), then frozen at $-80^{\circ} \mathrm{C}$.

From September 2010 through October 2011, adult Panulirus argus tissues were obtained directly from fishermen as fresh or recently frozen tissue samples (5th walking leg) from locations throughout the Caribbean (Fig. 1, Table 1). In most cases, approximately 100 lobsters were sampled from each country or sample location (see Table 1), and carapace length and sex were taken for each lobster. Samples, which consisted of a 1-2 cm piece of a walking leg preserved in clear rum $(40 \%$ ethanol, 80 proof), were shipped to the Virginia Institute of Marine Science and transferred upon receipt into $95 \%$ ethanol for long-term storage in preparation for genetic analysis. 


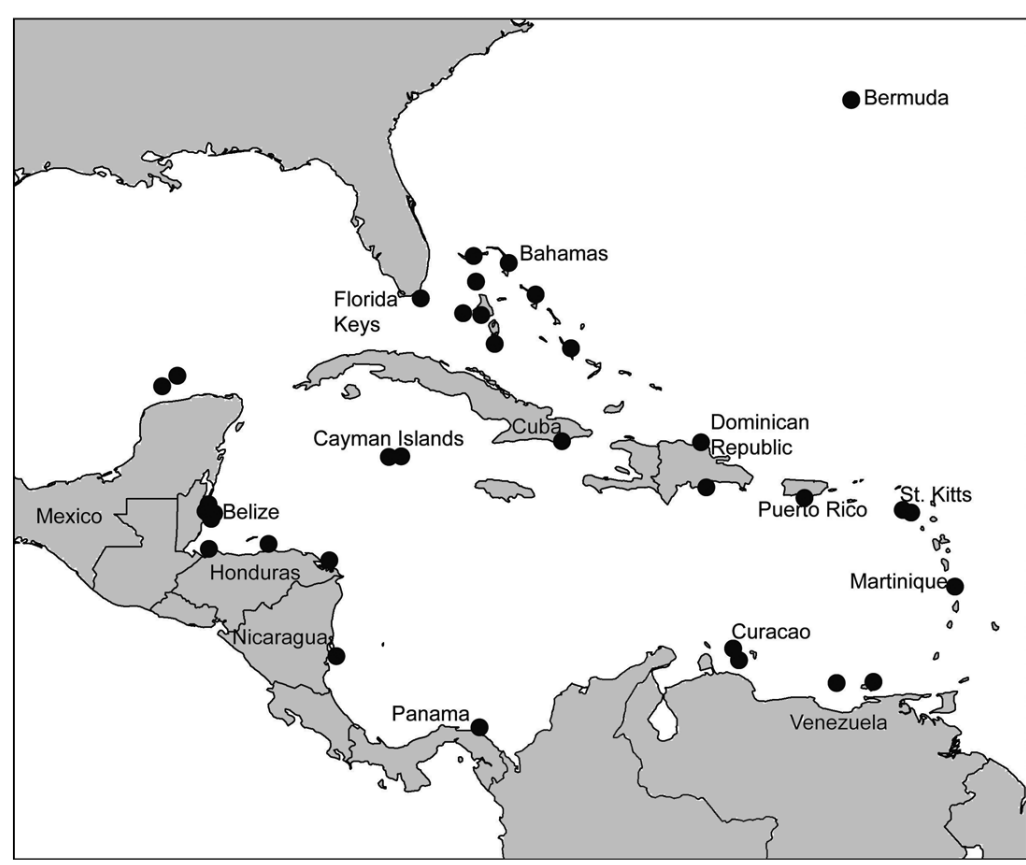

Fig. 1. Sampling locations (•) for Panulirus argus ume of $25 \mu \mathrm{l}$. An additional control reaction containing $2.5 \mu \mathrm{l}$ of doubledistilled water plus PCR reagents in the above concentrations was included as a separate control (no DNA). The thermocycling parameters were an initial denaturation step at $94^{\circ} \mathrm{C}$ for $5 \mathrm{~min}$, followed by 40 cycles of $94^{\circ} \mathrm{C}$ for $45 \mathrm{~s}$, $63^{\circ} \mathrm{C}$ for $45 \mathrm{~s}, 72^{\circ} \mathrm{C}$ for $1 \mathrm{~min}$, all followed by a final elongation step at $72^{\circ} \mathrm{C}$ for $10 \mathrm{~min}$. Aliquots of $10 \mu \mathrm{l}$ of the PaV1 PCR product or $6 \mu \mathrm{l}$ of the SSU product were loaded onto a $2 \%$ agarose gel $(\mathrm{w} / \mathrm{v})$, electrophoresed at $100 \mathrm{~V}$, stained with ethidium bromide, and examined under UV light. Images were recorded using the Alpha Innotech FluorChem ${ }^{\circledR}$ imaging system. We determined previously that the sensitivity of the modified PCR protocol is $0.02 \mathrm{fg} \mathrm{l}^{-1}$ viral DNA or $0.05 \mathrm{fg}$ of viral DNA per PCR reaction using plasmid DNA of the viral sequence (Moss et al. 2012).

\section{Molecular diagnostics and DNA sequencing}

Genomic DNA was extracted using Chelex resin (Bio-Rad). Using sterile methods, aliquots of $\sim 15 \mathrm{mg}$ of tissue or $150 \mu \mathrm{l}$ of hemolymph in anticoagulant were incubated with $50 \mu \mathrm{l}$ of $10 \%$ Chelex resin (w/v) and $12 \mu \mathrm{l}$ of Proteinase K (Qiagen) at $60^{\circ} \mathrm{C}$ for approximately $4 \mathrm{~h}$. Once tissue lysis was complete, samples were vortexed for $15 \mathrm{~s}$, heated at $100^{\circ} \mathrm{C}$ for $10 \mathrm{~min}$, vortexed briefly again, and then centrifuged at $13600 \mathrm{rpm}(20000 \times g)$ for $1 \mathrm{~min}$. The DNA (supernatant) was removed and stored at either $-20^{\circ} \mathrm{C}$ or $4^{\circ} \mathrm{C}$ prior to genetic analysis.

For quality control, genomic DNA from each lobster was assessed by amplifying the small subunit ribosomal RNA (SSU) using 'universal' SSU primers modified from Medlin et al. (1988) (see Moss et al. 2006, 2012). The amplified target DNA fragment was approximately $1800 \mathrm{bp}$ in length.

Diagnosis of PaV1 was done using PCR primers published previously (Montgomery-Fullerton et al. 2007), with modifications to reagent concentrations, thermocycling parameters, and reaction volume as described in Moss et al. (2012). The concentrations of the assay reagents were $1 \times$ PCR buffer $(20 \mathrm{mM}$ Tris$\mathrm{HCl}, \mathrm{pH}$ 8.4; $50 \mathrm{mM} \mathrm{KCl}), 0.2 \mathrm{mg} \mathrm{ml}^{-1}$ bovine serum

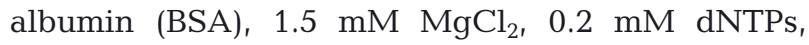
$0.5 \mu \mathrm{M} 45 \mathrm{aF}$ (forward primer), $0.5 \mu \mathrm{M} 543 \mathrm{aR}$ (reverse primer), and 1.0 unit Taq polymerase (Invitrogen). Aliquots of $2.5 \mu \mathrm{l}$ of lobster genomic DNA were added to $22.5 \mu \mathrm{l}$ of PCR reagents for a final PCR vol-
Amplification products from all spiny lobsters found to be PCR-positive for PaV1 were cloned and sequenced. Briefly, between 4 and 8 clones were sequenced per sample. PCR products of the correct size $(\sim 500 \mathrm{bp})$ were cloned into the plasmid pCR ${ }^{\circledR} 4$ TOPO and then transformed into Escherichia coli using a TOPO TA Cloning ${ }^{\circledR}$ Kit (Invitrogen), using half the manufacturer's recommendation of vector and chemically competent cells. Selection was based on ampicillin resistance. Transformed bacterial colonies were screened for inserts using a boil-prep method followed by PCR amplification using the M13 vector primers (Moss et al. 2006). Before sequencing, PCR products were treated with shrimp alkaline phosphatase (SAP) and exonuclease I (Exo I) (Amersham Biosciences) to remove excess oligonucleotides and dNTPs. Bidirectional sequencing was performed using the Big Dye Terminator Kit v.3.1 (Applied Biosystems) with M13 sequencing primers in $5 \mu \mathrm{l}$ reactions, with 1/8 the concentration of Big Dye recommended by the manufacturer's protocols. Sequence products were re-suspended in $20 \mu \mathrm{l}$ of Hi-Di formamide (Applied Biosystems), and $10 \mu \mathrm{l}$ of each were electrophoretically separated on an ABI 3130 Prism Genetic Analyzer.

Vector trimming and sequence editing were performed using CodonCode Aligner v.3.7.1.1. Sequences were aligned using the ClustalW algorithm in MacVector v.12.5.1. Settings for pairwise alignment were an open gap penalty of 10.0 and an extend gap 
Table 1. Panulirus argus virus 1 (PaV1) infecting P. argus. Location and dates where adult lobsters were sampled. Tissue samples are from different individuals; prevalence: percentage of lobsters that were PCR positive relative to the total number sampled. Totals in bold

\begin{tabular}{|c|c|c|c|c|c|}
\hline Country & Location & Date sampled & $\begin{array}{l}\text { No. of } \\
\text { samples }\end{array}$ & $\begin{array}{c}\text { Prevalence } \\
(\%)\end{array}$ & $95 \% \mathrm{CI}$ \\
\hline \multirow[t]{9}{*}{ Bahamas } & Abaco-Sandy Point & Oct 2010 & 98 & 0 & $0.0-3.9$ \\
\hline & Andros-Fresh Creek & Oct 2010 & 77 & 0 & $0.0-4.9$ \\
\hline & Berry Islands & Nov 2010 & 106 & 0.9 & $0.1-5.2$ \\
\hline & Grand Bahama-West End & Nov 2010 & 99 & 1.0 & $0.2-5.6$ \\
\hline & Great Bahama Bank-Guanchos Cay & Oct 2010 & 104 & 0 & $0.0-3.6$ \\
\hline & Long Island & Oct 2010 & 93 & 0 & $0.0-4.0$ \\
\hline & New Providence-Eleuthra Bank & Nov 2010 & 106 & 1.9 & $0.5-6.7$ \\
\hline & Great Bahama Bank-Orange Cay & Nov 2010 & 105 & 0 & $0.0-3.6$ \\
\hline & & & 788 & 0.5 & $0.1-1.3$ \\
\hline \multirow[t]{7}{*}{ Belize } & Caye Caulker & Feb 2010 & 25 & 4.0 & $0.7-20.7$ \\
\hline & Hol Chan Reserve & Feb 2010 & 2 & 0 & 0 \\
\hline & Glovers Atoll & Mar 2010 & 62 & 3.2 & $0.9-11.2$ \\
\hline & Little Water Caye & Mar 2010 & 3 & 0 & 0 \\
\hline & Snake Bank & Feb 2010 & 8 & 0 & 0 \\
\hline & South Water Caye & Feb 2010 & 2 & 0 & 0 \\
\hline & & & 102 & 2.9 & $1.0-8.4$ \\
\hline Bermuda & & Oct 2010 & 102 & 0.0 & $0.0-3.7$ \\
\hline \multirow[t]{3}{*}{ Cayman Islands } & Grand Cayman & Oct 2010 & 102 & 0.0 & $0.0-3.7$ \\
\hline & Little Cayman & Oct 2010 & 93 & 0.0 & $0.0-4.1$ \\
\hline & & & 195 & 0.0 & $0.0-2.0$ \\
\hline \multirow[t]{3}{*}{ Cuba } & Guantanamo Bay & Mar 2011 & 48 & 4.2 & $1.1-14.3$ \\
\hline & Guantanamo Bay & Nov 2011 & 31 & 9.7 & $3.2-25.7$ \\
\hline & & & 79 & 6.3 & $2.7-14.1$ \\
\hline \multirow[t]{7}{*}{ Curacao } & North shore (various) & Nov 2010 & 31 & 0 & $0.0-11.8$ \\
\hline & North shore (various) & Nov 2010 & 15 & 0 & $0.0-23.2$ \\
\hline & North shore-Wakawa & Nov 2010 & 12 & 0 & $0.0-28.3$ \\
\hline & South shore-Snakebaai & Nov 2010 & 2 & 0 & 0 \\
\hline & South shore-Caracasbaai & Nov 2010 & 9 & 0 & 0 \\
\hline & Perla Del Mar Restaurant & Nov 2010 & 51 & 0 & $0.0-7.3$ \\
\hline & & & 120 & $\mathbf{0}$ & $0.0-0.32$ \\
\hline \multirow[t]{3}{*}{ Dominican Republic } & North coast & Aug 2010 & 99 & 3.0 & $1.0-8.6$ \\
\hline & South coast & Aug 2010 & 111 & 5.4 & $2.5-11.4$ \\
\hline & & & 210 & 4.3 & $2.3-8.0$ \\
\hline \multirow[t]{4}{*}{ Honduras } & Cayos Cochinos & Mar 2011 & 96 & 3.1 & $1.1-8.9$ \\
\hline & Middle Bank & Mar 2011 & 51 & 0.0 & $0.0-7.3$ \\
\hline & Banco Oneido & Mar 2011 & 50 & 2.0 & $0.3-10.8$ \\
\hline & & & 197 & 2.0 & $0.8-5.1$ \\
\hline \multirow[t]{5}{*}{ Mexico } & Desterrada Key & Oct. 2010 & 72 & 5.6 & $2.1-13.6$ \\
\hline & Desparecida & Oct 2010 & 27 & 3.7 & $0.6-19.3$ \\
\hline & Isla Chica & Oct 2010 & 1 & 0 & 0 \\
\hline & Isla Perez & Oct 2010 & 1 & 0 & 0 \\
\hline & & & 101 & 4.9 & $2.1-11.2$ \\
\hline Martinique & La Trinite & Apr-Oct 2011 & 101 & $\mathbf{0}$ & $0.0-3.8$ \\
\hline Nicaragua & Corn Island & Sep 2010 & 99 & $\mathbf{0}$ & $0.0-3.8$ \\
\hline Panama & San Blas & Jul-Sep 2010 & 99 & 1.0 & $0.2-5.6$ \\
\hline Puerto Rico & Mayaguez & Oct 2010-Apr 2011 & 41 & 17 & $8.3-31.8$ \\
\hline \multirow[t]{3}{*}{ St. Kitts } & Dieppe Bay & Aug 2010 & 88 & 0 & $0.0-0.43$ \\
\hline & Sandy Bay & Aug 2010 & 33 & 0 & $0.0-11.1$ \\
\hline & & & 121 & $\mathbf{0}$ & $0.0-3.1$ \\
\hline \multirow[t]{2}{*}{ United States } & Lower Keys & & & & \\
\hline & Middle Keys & $\begin{array}{c}\text { Aug-Nov, } \\
\text { Jan-Mar 2008-2009 }\end{array}$ & 502 & 11.0 & $8.5-14.0$ \\
\hline \multirow[t]{3}{*}{ Venezuela } & Isla Margarita & Dec 2010 & 32 & 0.0 & $0.0-11.5$ \\
\hline & Los Roques & Dec 2010 & 102 & 0.0 & $0.0-3.7$ \\
\hline & & & 134 & 0.0 & $0.0-2.8$ \\
\hline
\end{tabular}


penalty of 0.1 . Settings for the multiple alignment stage were an open gap penalty of 10.0 and an extend gap penalty of 0.05. Following ClustalW alignment, the resulting alignment was edited by hand. Sequences were examined for unique alleles using Collapse v.1.2. Measures of genetic distance and nucleotide diversity were performed using MEGA v.5.0 (Tamura et al. 2011).

To limit the possibility of counting PCR error or sequencing misreads as single nucleotide polymorphisms (SNPs), only those SNPs observed greater than 5 times at a single locus within the data set were counted in the analysis. We used 5 as the minimum number to establish an SNP as authentic because Taq error rates for PCR are estimated as $1.1 \times 10^{-4}$ base substitutions per bp (Tindall \& Kunkel 1988), meaning that more than 3 or 4 errors at any single location would be highly unlikely.

\section{Rarefaction analysis}

For cost-effectiveness, efficiency in sample processing, and quality control, we examined how the presence of alleles (allele richness) varied with the number of infected lobsters examined and the number of clones analyzed (4 vs. 8 bacterial clones sequenced per infected lobster). Rarefaction analysis on a preliminary data set was used to examine allele richness. Values for Cole's rarefaction were estimated using EstimateS 8.0 (Colwell 2006). In the first analysis, common and rare alleles from all of the clones (4 or 8 clones per infected lobster; see 'Molecular diagnostics and DNA sequencing') were used to examine allele richness. In the second analysis, we asked whether common alleles were represented in both the 4-clone and 8-clone data sets. Common alleles were defined as those present in 3 or more infected lobsters using 8 clones from each, or 2 or more lobsters using 4 clones from each. For each analysis, the number of clones ( 4 or 8 ) examined were run separately, and the presence of an allele was counted as 1 when 1 or more clones from an infected lobster had that allele.

\section{RESULTS}

PaV1 viral DNA was detected in adult Panulirus argus using PCR in 9 of the 16 countries surveyed (Table 1). In general, PaV1 was found in countries in the northern and western Caribbean Sea, but it was absent from the southeastern locations, particularly the islands of the Lesser Antilles. The highest prevalence of PaV1 was from Puerto Rico at $17 \%$ (out of a total sample size $[\mathrm{n}]=41$ ), followed by Florida at $11 \%$ $(\mathrm{n}=502)$. We undertook extensive sampling around the Bahamas ( $\mathrm{n}=788$ ) as part of an additional study (M. J. Butler et al. unpubl.). Collectively, the prevalence there was low $(0.5 \%)$, and patchily distributed, with prevalence of 1 to $2 \%$ at 3 of 8 locations.

When all DNA sequences of the PaV1 amplicon were aligned, the total alignment length was $479 \mathrm{bp}$ (primer sequences removed). Overall genetic distance (uncorrected p-values) between the PaV1 viral DNA sequences obtained from adult Panulirus argus was 0.0053 , and mean nucleotide diversity was 0.0045 . Whereas within-group diversity was low overall, the geographic location with the highest average withingroup genetic distance was the Dominican Republic (0.0060), and the lowest was Honduras (0.0004) (Table 2). Genetic similarity between regions was analyzed using between-group genetic distance. The most genetically similar locations were Mexico and Honduras (0.0016) and Mexico and Belize (0.0017); the most genetically distant were the Bahamas and the Dominican Republic (0.0100) (Table 3).

PaV1 had a high allele richness, with 55 unique alleles identified from infected lobsters in which 8 clones were sequenced ( $\mathrm{n}=57$ infected lobsters), and 61 unique alleles when 4 clones were sequenced ( $\mathrm{n}=90$ infected lobsters) (Fig. 2). The 4-clone data set had a higher sample size; hence, more unique alleles were found therein. When common and rare alleles were analyzed together, allele richness did not show an asymptote in either the 4-clone or the 8-clone data; however, the 8-clone data had a steeper trajectory, indicating that somewhat more rare alleles were found when more clones were sequenced. The 4 -clone data set identified $100 \%$ of the total number of alleles present. In the analysis of common alleles

Table 2. Panulirus argus virus 1 (PaV1) infecting $P$. argus. Average within-group genetic distance (uncorrected p-value) of DNA sequences of PaV1 obtained from adult spiny lobster

\begin{tabular}{|lc|}
\hline Location & Average genetic distance \\
\hline Bahamas & 0.0053 \\
Belize & 0.0027 \\
Cuba & 0.0039 \\
Dominican Republic & 0.0060 \\
Honduras & 0.0004 \\
Florida Keys & 0.0047 \\
Mexico & 0.0024 \\
Panama & 0.0048 \\
Puerto Rico & 0.0041 \\
\hline
\end{tabular}


Table 3. Panulirus argus virus 1 (PaV1) infecting P. argus. Average between-group genetic distance (uncorrected p-value) of DNA sequences of PaV1 obtained from adult spiny lobsters between sampling locations

\begin{tabular}{|c|c|c|c|c|c|c|c|c|c|}
\hline & $\begin{array}{c}\text { Puerto } \\
\text { Rico }\end{array}$ & Panama & Mexico & Honduras & $\begin{array}{c}\text { Dominican } \\
\text { Republic }\end{array}$ & Cuba & Belize & Bahamas & $\begin{array}{c}\text { Florida, } \\
\text { USA }\end{array}$ \\
\hline Puerto Rico & - & & & & & & & & \\
\hline Panama & 0.0053 & - & & & & & & & \\
\hline Mexico & 0.0040 & 0.0038 & - & & & & & & \\
\hline Honduras & 0.0033 & 0.0027 & 0.0016 & - & & & & & \\
\hline Dominican Republic & 0.0064 & 0.0058 & 0.0047 & 0.0035 & - & & & & \\
\hline Cuba & 0.0054 & 0.0047 & 0.0035 & 0.0023 & 0.0054 & - & & & \\
\hline Belize & 0.0048 & 0.0041 & 0.0029 & 0.0017 & 0.0048 & 0.0035 & - & & \\
\hline Bahamas & 0.0094 & 0.0093 & 0.0082 & 0.0071 & 0.0100 & 0.0091 & 0.0083 & - & \\
\hline Florida, USA & 0.0057 & 0.0055 & 0.0043 & 0.0032 & 0.0063 & 0.0052 & 0.0045 & 0.0066 & - \\
\hline
\end{tabular}

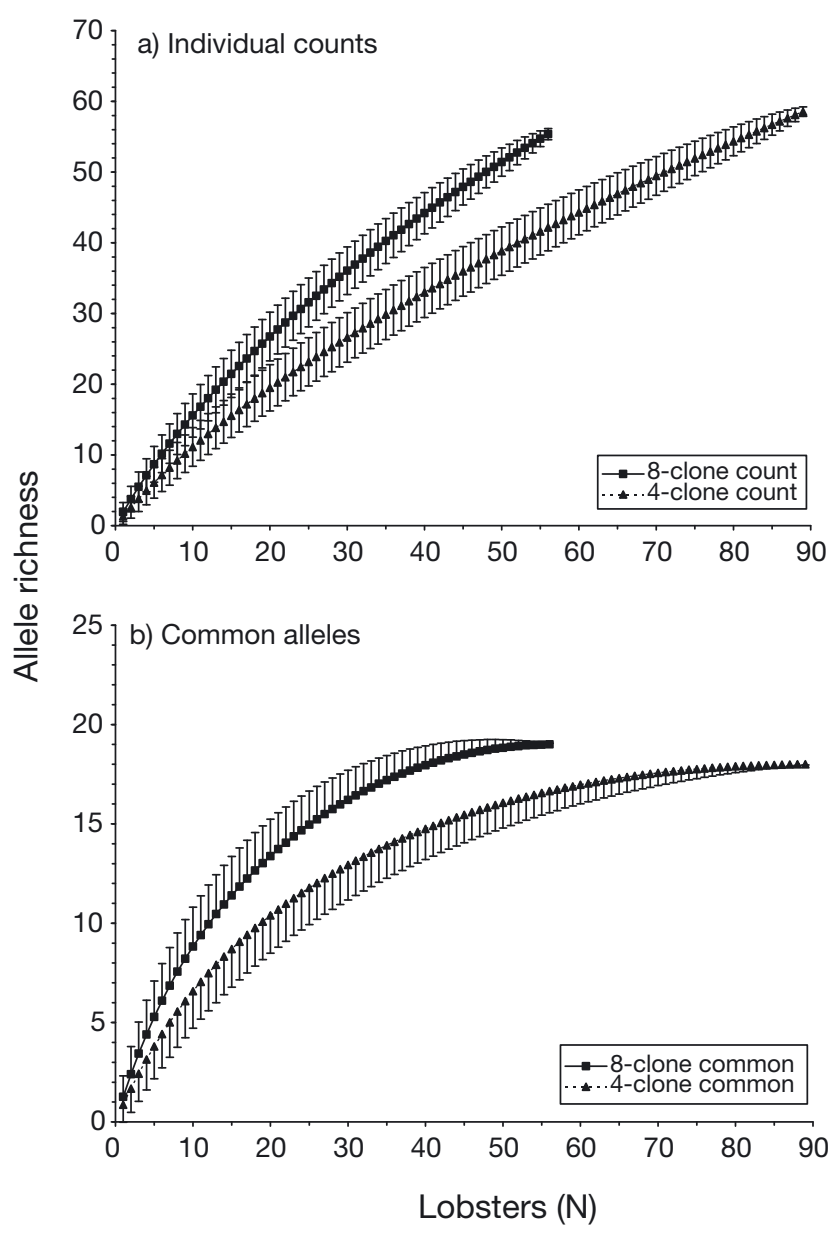

Fig. 2. Panulirus argus virus $1(\mathrm{PaV} 1)$ infecting $P$. argus. Rarefaction analysis between 4-clone and 8-clone data sets for lobsters infected with PaV1. (a) Analysis of all alleles present in the data sets showing no approaching asymptote. (b) Analysis of common alleles indicating the number of lobsters needed to identify all of the common alleles (1 seen in more than 2 or 3 lobsters in 4- vs. 8-clone data sets, respectively) if sequencing 4 vs. 8 clones per lobster sample. Both sets are identifying the same common alleles $(\mathrm{n}=19)$, allele richness showed a distinct asymptote in both the 8-clone data set and the 4-clone data set, indicating that common alleles were representative in either set (Fig. 2b). The rarefaction analysis on common alleles indicated that DNA sequences of PaV1 from a total of 4 clones per lobster were representative of the population and that significant cost savings could be obtained using only 4 clones per lobster rather than 8 clones. Thus, 4 clones per infected lobster were used in the final analyses discussed below.

Many of the same polymorphisms observed previously (Moss et al. 2012) were found in other locations (Table 4), in addition to 19 new variable loci. Viral sequences contained 3 regions with microsatellites as well as many SNPs (Table 4). SNPs were recorded as any SNP that was observed $\geq 5$ times in the data set. Thirty-eight unique sequences, or alleles, were new to the present study (Table 5). To examine the distribution of alleles and make inferences regarding sharing of alleles among regions, we combined data from Moss et al. (2012) with the present study (including viral alleles seen in postlarvae, EBJs, and juveniles from a viral mutation study). However, we limited the data set to only 4 clones per lobster as determined by rarefaction analysis (see previous paragraph). The most common allele was Allele 26 (frequency: 16\%), followed by $12(12 \%), 41(10 \%)$, and $9(9 \%)$; these 4 alleles were found in $47 \%$ of the clones analyzed. Single alleles constituted 29 of the 61 alleles observed. Representative sequences of all alleles have been deposited in GenBank (accession nos. JX987103 to JX987130).

Allele diversity was highest in Cuba (9 alleles), followed by the Dominican Republic (8 alleles). Diversity was lowest in Honduras, but the low prevalence limited the number of sequences obtained for PaV1 from that region. The greatest proportion of unique 
Table 4. Panulirus argus virus 1 (PaV1) infecting P. argus. Positions of PaV1 nucleotide variation. Superscripts next to microsatellite sequences indicate number of repeats observed. For single nucleotide polymorphism (SNP) notation, the most common base observed is listed first, followed by the observed base change. Bold text indicates polymorphisms found previously (Moss et al. 2012)

\begin{tabular}{|c|c|}
\hline Base position & Variation \\
\hline 10-33 & $(\mathrm{CGA})^{4-8}$ \\
\hline 24 & $\mathrm{~A} / \mathrm{G}$ \\
\hline $35-36$ & $\mathrm{AG} / \mathrm{GA}$ \\
\hline 70 & $\mathrm{C} / \mathrm{T}$ \\
\hline 87 & $\mathrm{~A} / \mathrm{C}$ \\
\hline $78-107$ & $(\mathrm{ACG})^{6-10}$ \\
\hline 130 & $\mathrm{G} / \mathrm{A}$ \\
\hline 113 & $\mathrm{~A} / \mathrm{C}$ \\
\hline 115 & $\mathrm{~A} / \mathrm{C}$ \\
\hline 119 & $\mathrm{~T} / \mathrm{C}$ \\
\hline 120 & $\mathrm{C} / \mathrm{T}$ \\
\hline $121-132$ & GAC GAC GAC GCC deletion \\
\hline 125 & $\mathrm{~A} / \mathrm{C}$ \\
\hline $129-143$ & $(\mathrm{CCG})^{2-4}$ \\
\hline 131 & $\mathrm{C} / \mathrm{A}$ \\
\hline 134 & $\mathrm{C} / \mathrm{A}$ \\
\hline 185 & $\mathrm{~A} / \mathrm{G}$ \\
\hline 236 & $\mathrm{~T} / \mathrm{C}$ \\
\hline 245 & $\mathrm{G} / \mathrm{A}$ \\
\hline 246 & $\mathrm{C} / \mathrm{T}$ \\
\hline 251 & $\mathbf{A} / \mathbf{G}$ \\
\hline 261 & $\mathrm{C} / \mathrm{T}$ \\
\hline 300 & $\mathrm{G} / \mathrm{A}$ \\
\hline 301 & $\mathrm{G} / \mathrm{T}$ \\
\hline 306 & $\mathbf{A} / \mathbf{G}$ \\
\hline 333 & $\mathrm{~A} / \mathrm{G}$ \\
\hline 363 & $\mathrm{C} / \mathrm{T}$ \\
\hline 375 & $\mathrm{C} / \mathrm{T}$ \\
\hline 399 & G/A \\
\hline 411 & T/C \\
\hline 416 & $\mathrm{~A} / \mathrm{G}$ \\
\hline 438 & $\mathrm{C} / \mathrm{T}$ \\
\hline
\end{tabular}

alleles occurred in adult lobsters from the Bahamas (80\% of alleles), Florida (57\%), the Dominican Republic (50\%), and Cuba (44\%), with 4 unique alleles each. Seven alleles were shared between 2 different locations (Fig. 3). One allele found in Florida was shared between the Dominican Republic and Puerto Rico (sharing between 3 locations), and 3 alleles found in Florida were shared with 3 additional locations (Allele 12: Dominican Republic, Mexico, and Panama; Allele 26: Belize, Dominican Republic, and Mexico; Allele 41: Cuba, Dominican Republic, and Honduras sharing between 4 locations).

In some cases, individual spiny lobsters were infected with multiple alleles of PaV1, which is suggestive of multiple infections (Table 6). In 13 cases, a single lobster contained 2 viral alleles, and in 3 instances, a single lobster contained 3 different viral alleles.

\section{DISCUSSION}

PaV1 is undetectable in adult lobsters via visual inspection, but genetic analysis demonstrates that $\mathrm{PaV} 1$ is widespread in adult spiny lobsters in central and northern portions of the Caribbean Sea, has a low prevalence in the southwestern Caribbean, and is absent from the 476 lobsters we sampled at the 4 southeastern Caribbean locations. Adult lobsters from Puerto Rico had the highest prevalence of PaV1 $(17 \%)$. Our results extend the known range of the virus in Belize, Cuba, Florida, Mexico, and St. Croix (US Virgin Islands) to now include Puerto Rico, the Dominican Republic, the Bahamas, Honduras, and Panama. Overall, the virus had a low prevalence $(0.5 \%)$ in adult lobsters from the Bahamas and was present at only 3 of 8 sites that we surveyed, indicating that it is not widely distributed there. The prevalence of PaV1 in adult lobsters from Cuba was 6.3\%, higher than that reported previously (Cruz Quintana et al. 2011: 1.5\% average from 4 locations). A possible explanation may be the difference in sampling locations, as the lobsters in the present study were collected from Guantanamo Bay, whereas the previous study examined lobsters from the Gulf of Batabanó. Our finding of 3.2 to $4.0 \%$ (mean: $2.0 \%$ ) prevalence off Belize is in sharp contrast to the $50 \%$ prevalence reported from frozen lobster tails exported from Belize (Huchin-Mian et al. 2009). That study did not state where the lobsters were caught in Belize, but the prevalence was far higher than that reported in the present study.

We did not find PaV1 in adult lobsters from the southeastern Caribbean locations (Martinique, St. Kitts, Venezuela, and Curaçao), nor from Bermuda. At least 100 lobsters were sampled from each of these locations. We cannot rule out the presence of the virus from these locations, as hundreds of animals would be required from each location to verify prevalence levels below 1.0\% (Gregory \& Blackburn 1991, Jovani \& Tella 2006), but if present, it has a very low prevalence in those areas. However, we speculate that the net movement of currents in the Caribbean basin from the southeast to the northwest (http://oceancurrents.rsmas.miami.edu/caribbean/ caribbean.html) may minimize the spread of the virus to 'upstream' locations in the eastern Caribbean.

The genetic diversity of PaV1 in the Caribbean Sea was high, with 61 unique viral alleles from 9 locations. Not only was the diversity high, but all locations except Honduras possessed alleles unique to those locations. For example, 2 of the 3 alleles observed in Panama were unique (66\%), only occurring 
Table 5. Distribution of Panulirus argus virus 1 (PaV1) alleles in Florida, USA, and the Caribbean Sea. Alleles in bold are those previously reported (Moss et al. 2012). Additional single nucleotide polymorphisms (SNPs) are reported as new alleles. Only 4 clones per lobster were used in this analysis. PLs: postlarvae; EBJs: early benthic juveniles $(<15 \mathrm{~mm}$ carapace length); FL: Florida; BA: Bahamas; BZ: Belize; CU: Cuba; DR: Dominican Republic; HO: Honduras; MX: Mexico; PN: Panama; PR; Puerto Rico

\begin{tabular}{|c|c|c|c|c|c|c|c|c|c|c|c|c|}
\hline Allele & FL PLs ${ }^{a}$ & $\mathrm{FL} \mathrm{EBJs}^{\mathrm{a}}$ & FL juveniles $^{\mathrm{a}}$ & FL adults & BA & $\mathrm{BZ}$ & $\mathrm{CU}$ & DR & $\mathrm{HO}$ & MX & $\mathrm{PN}$ & PR \\
\hline 1 & & 3 & & & & & & & & 4 & & \\
\hline 2 & & 1 & & & & & & & & & & \\
\hline 3 & & 22 & & & & & & & & & & \\
\hline 4 & & 5 & & & & & 4 & & & & & \\
\hline 5 & & 1 & & & & & & & & & & \\
\hline 6 & & 4 & & & & & & & & & & \\
\hline 7 & & 1 & & & & & & & & & & \\
\hline 8 & & 1 & & & & & & & & & & \\
\hline 9 & & 34 & & & & & & & & & & \\
\hline 10 & 4 & 7 & & & & 1 & & & & & & \\
\hline 11 & & 1 & & & & & & & & & & \\
\hline 12 & 22 & 14 & & & & & & 2 & & 2 & 2 & \\
\hline 13 & & 1 & & & & & & & & & & \\
\hline 14 & & 2 & & & & & & & & & & \\
\hline 15 & & 1 & & & & & & & & & & \\
\hline 16 & 1 & & 1 & & & & & 1 & & & & 1 \\
\hline 17 & 1 & & & & & & & & & & & \\
\hline 18 & 1 & & & & & & & & & & & \\
\hline 19 & 1 & & & & & & & & & & & \\
\hline 20 & 1 & & & & & & & & & & & \\
\hline 21 & 8 & & & & & & & & & & & \\
\hline 22 & 1 & & & & & & & & & & & 1 \\
\hline 23 & & 1 & & & & & & & & & & \\
\hline 24 & & 3 & & & & & & & & & & \\
\hline 25 & & 1 & & & & & & & & & & \\
\hline 26 & & 3 & 21 & 11 & & 10 & & 2 & & 11 & & \\
\hline 27 & & & 2 & & & & & & & & & \\
\hline 28 & & 1 & & & & & & & & & & \\
\hline 28 & & 8 & & & 4 & & & & & & & \\
\hline 30 & & 1 & & & & & & & & & & 15 \\
\hline 31 & & 3 & & & & & & & & & & \\
\hline 32 & & 1 & & & & & & & & & & \\
\hline 33 & & & & & & & & & & & & 3 \\
\hline 34 & & & & & & & & & & & & 1 \\
\hline 35 & & & & & & & & & & & & 1 \\
\hline 36 & & & & & & & & & & & & 4 \\
\hline 37 & & & & & & & & & & & 1 & \\
\hline 38 & & & & & & & & & & & 1 & \\
\hline 39 & & & & & & & & & & 1 & & \\
\hline 40 & & & & & & & & & & 4 & & \\
\hline 41 & & & & 3 & & & 3 & 20 & 12 & & & \\
\hline 42 & & & & & & & 1 & 1 & & & & \\
\hline 43 & & & & & & & & 4 & & & & \\
\hline 44 & & & & & & & & 1 & & & & \\
\hline 45 & & & & & & & & 1 & & & & \\
\hline 46 & & & & & & & 1 & & & & & \\
\hline 47 & & & & & & & 3 & & & & & \\
\hline 48 & & & & & & 3 & 4 & & & & & \\
\hline 49 & & & & 1 & & & 1 & & & & & \\
\hline 50 & & & & & & & 2 & & & & & \\
\hline 51 & & & & & & & 1 & & & & & \\
\hline 52 & & & & & & 1 & & & & & & \\
\hline 53 & & & & & & 1 & & & & & & \\
\hline 54 & & & & & 6 & & & & & & & \\
\hline 55 & & & & & 4 & & & & & & & \\
\hline 56 & & & & & 1 & & & & & & & \\
\hline 57 & & & & & 1 & & & & & & & \\
\hline 58 & & & & 4 & & & & & & & & \\
\hline 59 & & & & 1 & & & & & & & & \\
\hline 60 & & & & 4 & & & & & & & & \\
\hline 61 & & & & 4 & & & & & & & & \\
\hline Total & 9 & 24 & 3 & 7 & 5 & 5 & 9 & 8 & 1 & 5 & 3 & 7 \\
\hline Unique & 5 & 16 & 1 & 4 & 4 & 2 & 4 & 4 & 0 & 2 & 2 & 3 \\
\hline
\end{tabular}


in Panama, whereas 4 of the 5 alleles found in the Bahamas were unique $(80 \%)$. This suggests that although many alleles are shared between sites, an indication of high viral genetic connectivity, some alleles were endemic to certain locations and thus may be useful indicators for defining host populations. Although the genetic distance between PaV1 from Mexico and Honduras was most similar (uncorrected p-distance: 0.0016), these 2 regions did not share alleles for PaV1. However, our samples from Mexico were obtained from Alacranes Reef in the Gulf of Mexico to the northwest of the Yucatan Peninsula, an area quite distinct hydrographically from Mesoamerica. So although the PaV1 samples from Belize were genetically similar to Mexico (0.0029 relatedness), they were more closely aligned with Honduras (0.0017); samples from Belize and Honduras only shared 1 viral allele.

Based on our existing DNA sequences, the most genetically distinct population of PaV1 was in the Bahamas. Samples of the virus from the Bahamas had relatively high between-group genetic distances compared to PaV1 in other regions. Bahamian PaV1 DNA sequences were genetically most different from the Dominican Republic (uncorrected p-distance: 0.0100) and shared no viral alleles. Given the close proximity of the Bahamas to the Dominican Republic,

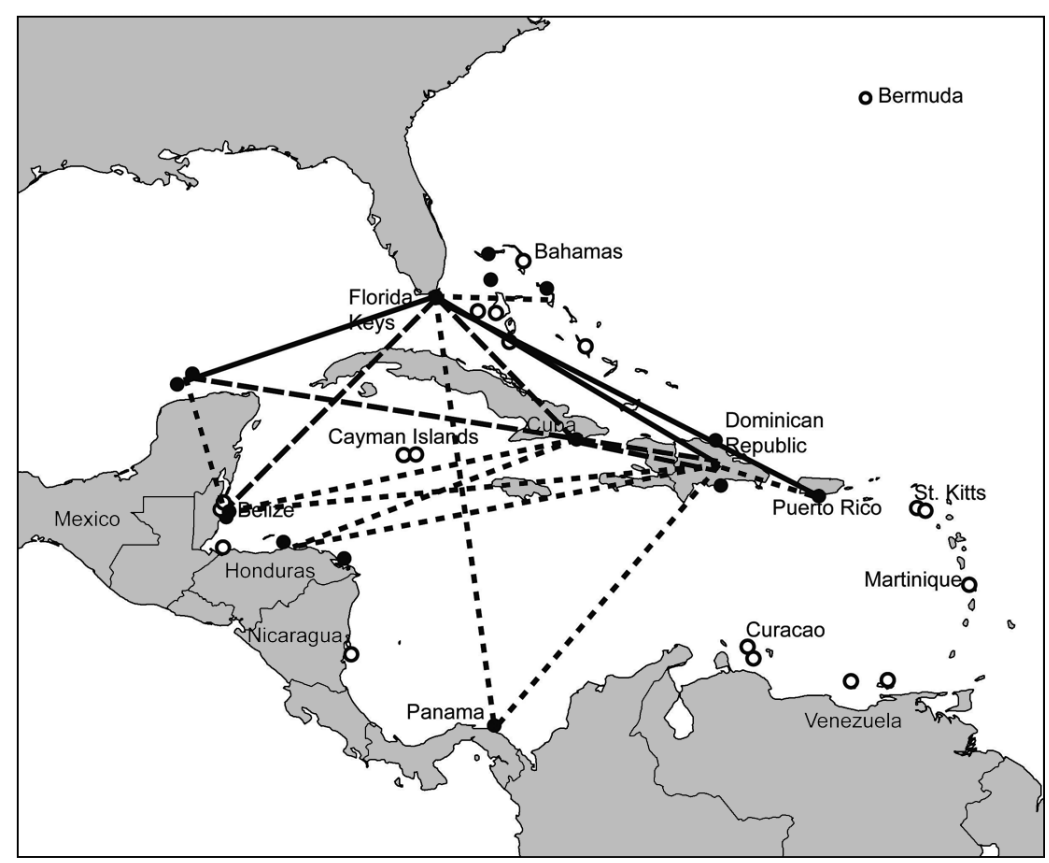

Fig. 3. Panulirus argus. Sampling locations (•), and genetic connectivity between populations with Panulirus argus virus 1 (PaV1). Locations where lobsters were sampled but where PaV1 was absent are indicated (O). Genetic connectivity: $3(-), 2(--)$, or 1 (- - -) viral allele(s) shared
Table 6. Panulirus argus virus 1 (PaV1) infecting P. argus. Frequency of multiple infections in spiny lobster. $\mathrm{N}=$ number of PaV1-positive samples sequenced from the specific location

\begin{tabular}{|lccc|}
\hline Location & N & 2 alleles & 3 alleles \\
\hline Bahamas & 4 & 1 & 1 \\
Belize & 4 & 2 & 0 \\
Cuba & 5 & 2 & 1 \\
Dominican Republic & 8 & 2 & 0 \\
Florida, USA & 7 & 4 & 0 \\
Honduras & 3 & 0 & 0 \\
Mexico & 5 & 1 & 0 \\
Puerto Rico & 7 & 0 & 1 \\
Panama & 1 & 1 & 0 \\
\hline
\end{tabular}

this may seem surprising. However, hydrographic modeling of larval lobster dispersal indicates that the complex bathymetry of the Bahamas constrains lobster population connectivity (Lipcius et al. 1997, Butler et al. 2011), which is also consistent with hydrodynamic modeling and empirical data on population connectivity of other species in the Bahamas (Cowen et al. 2006, Galindo et al. 2006). Indeed, $80 \%$ of the PaV1 alleles from Bahamian lobster samples were unique and shared only 1 viral allele with Florida, indicative of a significant barrier to viral gene flow that largely isolates the Bahamas.

The overall genetic distance among viral DNA sequences from adult spiny lobsters was 0.0053 . With the exception of the viral alleles from the Bahamas, our phylogenetic analyses of viral alleles, using both neighborjoining and parsimony analyses, reveals little population structure based on geographic location (J. Moss unpubl. data). This is comparable to other reports that have discerned little structure in the population genetics of Panulirus argus, using allozymes (Menzies 1980), restriction fragment length polymorphisms in mitochondrial genes (mtDNA RFLP) (Silberman et al. 1994), sequencing of the mitochondrial 16S ribosomal gene (Sarver et al. 1998), and segments of the mitochondrial cytochrome $c$ oxidase subunit I gene (Naro-Maciel et al. 2011). However, a recent preliminary analysis of lobster genetic structure in Mesoamerica based on neutral genetic microsatellite analyses suggests that subregional population structure 
may exist in that region (Truelove et al. 2012). The long planktonic larval duration (PLD) of P. argus (5 to $7 \mathrm{mo}$; Goldstein et al. 2008), and thus potential for long distance dispersal (Lyons 1980, Silberman et al. 1994, Briones-Fourzán et al. 2008, Naro-Maciel et al. 2011), provide a mechanism for what is generally considered a panmictic population. However, when biophysical models incorporate larval behavior with complex current models, the results indicate that $P$. argus larvae are often entrained within a few hundred kilometers of where they were spawned (Butler et al. 2011). This is particularly so in environments with retentive oceanographic circulation patterns, such as the Bahamas, where larvae are most likely to be retained, possibly facilitating the rise of unique alleles for both the host and the virus. Still, biophysical models predict that nearly $10 \%$ of $P$. argus larvae disperse $>1000 \mathrm{~km}$ from many Caribbean spawning sites, highlighting the disparity between demographically relevant and genetically relevant population connectivity (Butler et al. 2011).

Given that PaV1 is widespread in spiny lobster populations throughout the northwestern Caribbean Sea, and viral alleles are often shared between distant locations, there is a high degree of disease connectivity in a large portion of the Caribbean. Yet, laboratory transmission of PaV1 among lobsters and in cell culture indicates that PaV1 is only viable for a few days in seawater (Butler et al. 2008, M. J. Butler et al. unpubl. data). Moreover, the depth of the seafloor separating lobster populations and the cold temperatures on the bottom of those deep channels are a barrier to deep sea movement of tropical spiny lobsters. So how can viral alleles be shared over such large distances in the Caribbean? Newly arriving lobster postlarvae in the Florida Keys have been diagnosed with PaV1 (Moss et al. 2012), and we have preliminary evidence for maternal transmission to the embryos (vertical transmission). Thus, larval transport is a potential means for dispersal of the virus through the Caribbean.

The viral diversity is highest within the Florida Keys, and this may either be a real phenomenon as currents from around the Caribbean move through the Florida Straits, or it could be an artifact of our sequencing a large number of PaV1 samples from the Florida Keys compared to other regions. Moreover, the large number of PaV1 alleles described ( $\mathrm{n}=61)$, their extensive geographic distribution, and the presence of unique alleles at most of the regions sampled is highly suggestive that the virus has been present in the Caribbean for a long time. That is, it is unlikely that $\mathrm{PaV} 1$ is a newly emergent pathogen.
Given that EBJs are highly susceptible to PaV1, and once infected, experience very high rates of mortality (Butler et al. 2008, Behringer et al. 2011), it is clear that PaV1 may have a significant effect on lobster fisheries. Caribbean-wide landings of spiny lobsters peaked during the period 1987-1997 but have since decreased by $55 \%$ in the $2000 \mathrm{~s}$, with environmental degradation and overexploitation generally blamed for the decline (Ehrhardt et al. 2010). Although PaV1 was first discovered in 1999 (Shields \& Behringer 2004), we do not know when it emerged nor do we know its primary mode(s) of dispersal. Yet, the most dramatic declines in spiny lobster landings in the past decade have been in Cuba (60\% mean landings decrease, PaV1 prevalence of $6.3 \%$ in adults) and Florida (50\% mean landings decrease, PaV1 prevalence of $11 \%$ in adults), 2 locations where PaV1 had a relatively high prevalence. Landings in the NicaraguaHonduras region have declined by less than $20 \%$ (Ehrhardt et al. 2010), and in the present study, PaV1 had a low prevalence in Honduras (2\%) and was absent from our 1 sample location in Nicaragua. In Florida, the prevalence of PaV1 has been reported as high as $11 \%$ in adult lobsters, whereas in some localized 'hot spots', prevalence in juveniles has reached as high as $60 \%$ (Behringer et al. 2011). Likewise, in Cuba, PaV1 prevalence in adults may be low $(0.83 \%)$ but has reached over $44 \%$ in juveniles in some locations (Cruz Quintana et al. 2011). Therefore, our estimates of PaV1 prevalence in Panulirus argus, based on sampling of adult lobsters alone, underestimates its prevalence in lobster populations where PaV1 prevalence is undoubtedly higher in juveniles, which are more difficult to sample.

The potential for damage by PaV1 to one of the Caribbean's most iconic and economically valuable fisheries underscores the need for management that considers the very real impact that PaV1 may have on lobster stocks. Estimates of natural mortality rates, especially for EBJs and juveniles, may be significantly higher if PaV1 is present. For example, based on mean prevalence of visible infections in juvenile lobsters from 2000 to 2010 (Behringer et al. 2011), we estimate that at least $24 \%$ of the settlers in Florida never recruit to fishery size due to mortality from PaV1 infection. Accordingly, we suggest that disease surveys be undertaken in adult and small juvenile stages in all nations with significant spiny lobster fisheries, and particularly those where the prevalence exceeds $1 \%$ in adult lobsters. 
Acknowledgements. We thank K. Wheeler, P. Coffey, P. O'Leary, and S. Katsuki for assistance with sample processing. We thank D. Parthree for assistance with GIS mapping of sample locations. Sampling of lobsters was also aided greatly by assistance from E. Wederforte (Curaçao), J. Azueta (Belize), T. Trott (Bermuda), and R. Wilkens (St. Kitts). This work was funded by National Science Foundation (NSF) grants OCE0136894 and OCE0929086. This is Virginia Institute of Marine Science (VIMS) contribution \#3261.

\section{LITERATURE CITED}

Behringer DC, Butler MJ IV, Shields JD (2008) Ecological and physiological effects of $\mathrm{PaV} 1$ on the Caribbean spiny lobster (Panulirus argus Latreille). J Exp Mar Biol Ecol 359:26-33

> Behringer DC, Butler MJ, Shields JD, Moss J (2011) Review of Panulirus argus virus $1-$ a decade after its discovery. Dis Aquat Org 94:153-160

Behringer DC, Moss J, Shields JD, Butler MJ (2012) PaV1 infection in the Florida spiny lobster fishery and its effects on trap function and disease transmission. Can J Fish Aquat Sci 69:136-144

Briones-Fourzán P, Candela J, Lozano-Álvarez E (2008) Post-larval settlement of the spiny lobster Panulirus argus along the Caribbean coast of Mexico: patterns, influence of physical factors, and possible sources of origin. Limnol Oceanogr 53:970-985

Butler MJ, Behringer DC, Shields JD (2008) Transmission of Panulirus argus virus 1 (PaV1) and its effect on the survival of juvenile Caribbean spiny lobster. Dis Aquat Org 79:173-182

Butler MJ, Paris CB, Goldstein JS, Matsuda H, Cowen RK (2011) Behavior constrains the dispersal of long-lived spiny lobster larvae. Mar Ecol Prog Ser 422:223-237

Colwell RK (2006) EstimateS: statistical estimation of species richness and shared species from samples, version 8 [software]. Available at: http://purl.oclc.org/estimates

Cowen RK, Paris CB, Srinivasan A (2006) Scaling of connectivity in marine populations. Science 311:522-527

Cruz Quintana Y, Rodríguez Canul R, Vidal Martínez VM (2011) First evidence of Panulirus argus Virus 1 (PaV1) in spiny lobster from Cuba and clinical estimation of its prevalence. Dis Aquat Org 93:141-147

Ehrhardt NM, Puga R, Butler MJ IV (2010) Large ecosystem dynamics and fishery management concepts: the Caribbean spiny lobster, Panulirus argus, fisheries. In: Fanning L, Mahon R, McConney P (eds) Towards marine ecosystem-based management in the wider Caribbean. Amsterdam University Press, Amsterdam, p 157-175

Florida Wildlife and Conservation Commission (2012) Commercial landings data. Available at: http://myfwc. com/research/saltwater/fishstats/commercial-fisheries/ landings-in-florida (accessed $20 \mathrm{Jul}$ 2012)

> Freitas R, Castro M (2005) Occurrence of Panulirus argus (Latreille,1804) (Decapoda, Palinuridae) in the northwest islands of the Cape Verde archipelago (central-east Atlantic). Crustaceana 78:1191-1201

> Galindo HM, Olson DB, Palumbi SR (2006) Seascape genetics: a coupled oceanographic-genetic model predicts population structure of Caribbean corals. Curr Biol 16: 1622-1626

Goldstein JS, Matsuda H, Takenouchi T, Butler MJ IV (2008) The complete development of larval Caribbean spiny lobster Panulirus argus (Latreille, 1804) in culture. J Crustac Biol 28:306-327

- Gregory RD, Blackburn TM (1991) Parasite prevalence and host sample size. Parasitol Today 7:316-318

> Huchin-Mian JP, Rodríguez-Canul R, Arias-Bañuelos E, Simá-Álvarez R, Pérez-Vega JA, Briones-Fourzán P, Lozano-Álvarez E (2008) Presence of Panulirus argus Virus 1 (PaV1) in juvenile spiny lobsters Panulirus argus from the Caribbean coast of Mexico. Dis Aquat Org 79: 153-156

Huchin-Mian JP, Briones-Fourzán P, Simá-Álvarez R, CruzQuintana Y and others (2009) Detection of Panulirus argus Virus 1 (PaV1) in exported frozen tails of subadultadult Caribbean spiny lobsters Panulirus argus. Dis Aquat Org 86:159-162

Jovani R, Tella JL (2006) Parasite prevalence and sample size: misconceptions and solutions. Trends Parasitol 22: 214-218

Li C, Shields JD, Ratzlaff RE, Butler MJ (2008) Pathology and hematology of the Caribbean spiny lobster experimentally infected with Panulirus argus virus 1 (PaV1). Virus Res 132:104-113

> Lipcius RN, Stockhausen WT, Eggleston DB, Marshall LS Jr, Hickey B (1997) Hydrodynamic decoupling of recruitment, habitat quality and adult abundance in the Caribbean spiny lobster: source-sink dynamics. Mar Freshw Res 48:807-816

> Lozano-Álvarez E, Briones-Fourzán P, Ramírez-Estévez A, Placencia-Sánchez D, Huchin-Mian JP, Rodríguez-Canul R (2008) Prevalence of Panulirus argus Virus 1 (PaV1) and habitation patterns of healthy and diseased Caribbean spiny lobsters in shelter-limited habitats. Dis Aquat Org 80:95-104

Lyons WG (1980) Possible sources of Florida's spiny lobster population. Proc Gulf Caribb Fish Inst 33:253-266

> Medlin L, Elwood HJ, Stickel S, Sogin ML (1988) The characterization of enzymatically amplified eukaryotic 16Slike rRNA-coding proteins. Gene 71:491-499

Menzies RA (1980) Biochemical population genetics and the spiny lobster larval recruitment problem: an update. Proc Gulf Caribb Fish Inst 33:230-243

Montgomery-Fullerton MM, Cooper RA, Kauffman KM, Shields JD, Ratzlaff RE (2007) Detection of Panulirus argus Virus 1 in Caribbean spiny lobsters. Dis Aquat Org 76:1-6

Moss JA, Burreson EM, Reece KS (2006) Advanced Perkinsus marinus infections in Crassostrea ariakensis maintained under laboratory conditions. J Shellfish Res 25: 65-72

> Moss J, Butler MJ, Behringer DC, Shields JD (2012) Genetic diversity of the Caribbean spiny lobster virus, Panulirus argus virus 1 (PaV1), and the discovery of PaV1 in lobster postlarvae. Aquat Biol 14:223-232

Naro-Maciel E, Reid B, Holmes KE, Brumbaugh DR, Martin M, DeSalle R (2011) Mitochondrial DNA sequence variation in spiny lobsters: population expansion, panmixia, and divergence. Mar Biol 158:2027-2041

Sarver SK, Silberman JD, Walsh PJ (1998) Mitochondrial DNA sequence evidence supporting the recognition of two subspecies or species of the Florida spiny lobster Panulirus argus. J Crustac Biol 18:177-186

Shields JD, Behringer DC (2004) A new pathogenic virus in the Caribbean spiny lobster Panulirus argus from the Florida Keys. Dis Aquat Org 59:109-118

Silberman JD, Sarver SK, Walsh PJ (1994) Mitochondrial 
DNA variation and population structure in the spiny lobster Panulirus argus. Mar Biol 120:601-608

Söderhäll K, Smith VJ (1983) Separation of the haemocyte populations of Carcinus maenas and other marine decapods, and prophenoloxidase distribution. Dev Comp Immunol 7:229-239

Tamura K, Peterson D, Peterson N, Stecher G, Nei M, Kumar S (2011) MEGA5: Molecular Evolutionary Genetics Analysis using maximum likelihood, evolutionary distance, and maximum parsimony methods. Mol Biol Evol 28:2731-2739

Tindall KR, Kunkel TA (1988) Fidelity of DNA synthesis by

Editorial responsibility: Grant Stentiford, Weymouth, UK
Thermus aquaticus DNA polymerase. Biochemistry 27: 6008-6013

Truelove NK, Burdfield-Steel E, Griffiths S, Ley-Cooper K and others (2012) Genetic connectivity of Caribbean spiny lobster (Panulirus argus) in Belize. Proc Gulf Caribb Fish Inst 64:463-467

Vondruska J (2010) Spiny lobster: Florida's commercial fishery, markets, and global landings and trade. Report no. SERO-FSSB-2010-04. National Marine Fisheries Service, NOAA, St. Petersburg, FL. Available at: http://sero. nmfs.noaa.gov/sf/pdfs/FSSB_2010-04_LOB_TRADE_RPT_ 23Aug10.pdf (accessed 19 Jul 2012)

Submitted: September 11, 2012; Accepted: February 11, 2013 Proofs received from author(s): May 1, 2013 